\title{
Design of a Mars Airplane Propulsion System for the Aerial Regional-scale Environmental Survey (ARES) Mission Concept
}

\author{
Christopher A. Kuhl ${ }^{1}$ \\ NASA Langley Research Center, Hampton, VA 23681
}

\begin{abstract}
The Aerial Regional-Scale Environmental Survey (ARES) is a Mars exploration mission concept that utilizes a rocket propelled airplane to take scientific measurements of atmospheric, surface, and subsurface phenomena. The liquid rocket propulsion system design has matured through several design cycles and trade studies since the inception of the ARES concept in 2002. This paper describes the process of selecting a bipropellant system over other propulsion system options, and provides details on the rocket system design, thrusters, propellant tank and PMD design, propellant isolation, and flow control hardware. The paper also summarizes computer model results of thruster plume interactions and simulated flight performance. The airplane has a $6.25 \mathrm{~m}$ wingspan with a total wet mass of $185 \mathrm{~kg}$ and has to ability to fly over $600 \mathrm{~km}$ through the atmosphere of Mars with $45 \mathrm{~kg}$ of MMH / MON3 propellant.
\end{abstract}

\section{Introduction}

THE Aerial Regional-Scale Environmental Survey (ARES) is a Mars exploration mission concept with the goal of taking 1 scientific measurements of the atmosphere, surface, and subsurface of Mars by using an airplane as the payload platform. ARES has evolved over several efforts, starting with a Mars Scout Phase-A study considering a 2007 launch opportunity, followed by a large investment by NASA Langley Research Center with the goal of reducing the risk of the atmospheric flight system. Finally, the concept was further matured and proposed to the Mars Scout program for a 2011 launch opportunity. This paper summarizes the design and development of the ARES airplane propulsion subsystem beginning with the inception of the ARES project in 2002 through the submittal of the Mars Scout proposal in July 2006.

\section{Mission Description}

The ARES mission expands upon the past Mars exploration missions of Viking, Mars Global Surveyor (MGS), Odyssey, and the Mars Exploration Rovers (MER), to examine the structure and evolution of Mars' atmosphere, surface, and interior. The ARES atmospheric flight system is designed to fly above the Southern Highlands to study crustal magnetism, atmospheric boundary layer composition, chemistry and dynamics, and also to search for near-surface water.

\section{A. Concept of Operations}

The ARES concept assumes a baseline launch date from Kennedy Space Center in October, 2011 on a Delta II 2925, placing it on a 10.4 month trajectory to Mars. ARES will utilize a Type II interplanetary trajectory with a series of five planned trajectory correction maneuvers (TCMs) with a final direct entry into Mars. The entry system (aeroshell and atmospheric flight system) will separate from the carrier spacecraft just before entering Mars atmosphere. The carrier spacecraft will then perform a divert maneuver to a Mars flyby trajectory, enabling it to relay to Earth the science and engineering data collected during the airplane flight. Mars Reconnaissance Orbiter (MRO) will serve as a redundant data return path for critical data. An overview of the mission concept is shown in Figure 1.

\footnotetext{
${ }^{1}$ Aerospace Engineer, Atmospheric Flight and Entry Systems Branch, M/S 489, AIAA Member. 


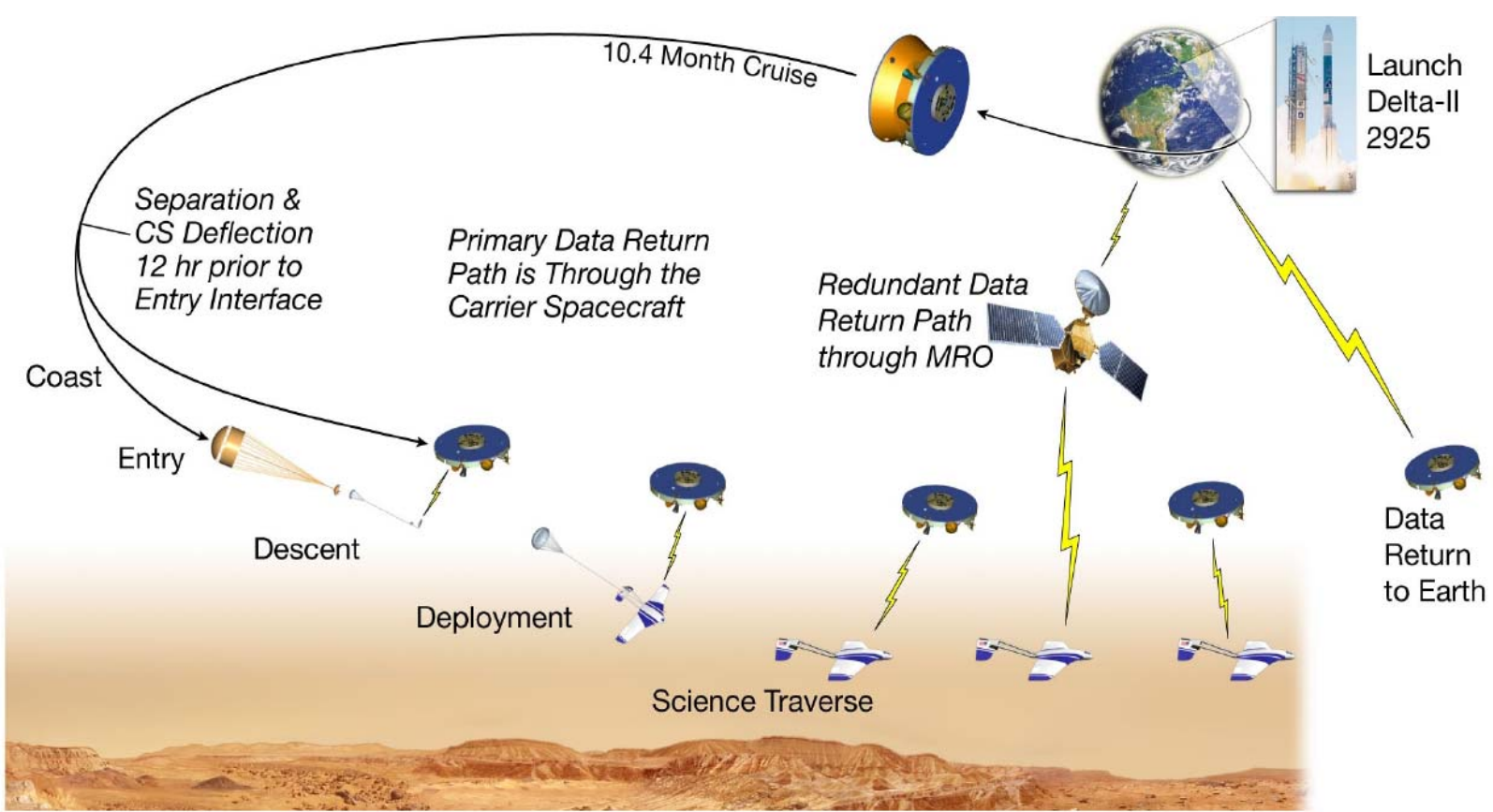

Figure 1. Mission Concept Overview. ARES uses the carrier spacecraft and MRO for dual data return paths.

\section{B. Target Flight Region}

Based on scientific objectives, the target region is defined by the intersection of two regions of interest; one region with highly variable crustal magnetism and the other region where water initiated atmospheric chemistry can be studied ${ }^{1}$. The combination of these two zones yields a large region spanning $20^{\circ}$ to $60^{\circ} \mathrm{S}$ latitude and $150^{\circ}$ to $210^{\circ} \mathrm{E}$ longitude (See Figure 2). During a science flight traverse of more than 70 minutes, the ARES rocket-propelled airplane will fly over $600 \mathrm{~km}$ obtaining measurements of crustal magnetism and the atmosphere. The reference traverse begins at a nominal delivery location of $\left(51.2^{\circ} \mathrm{S}, 180.0^{\circ} \mathrm{E}\right)$ and travels $>1.7^{\circ}$ south prior to performing an aeromagnetic survey defined by two additional

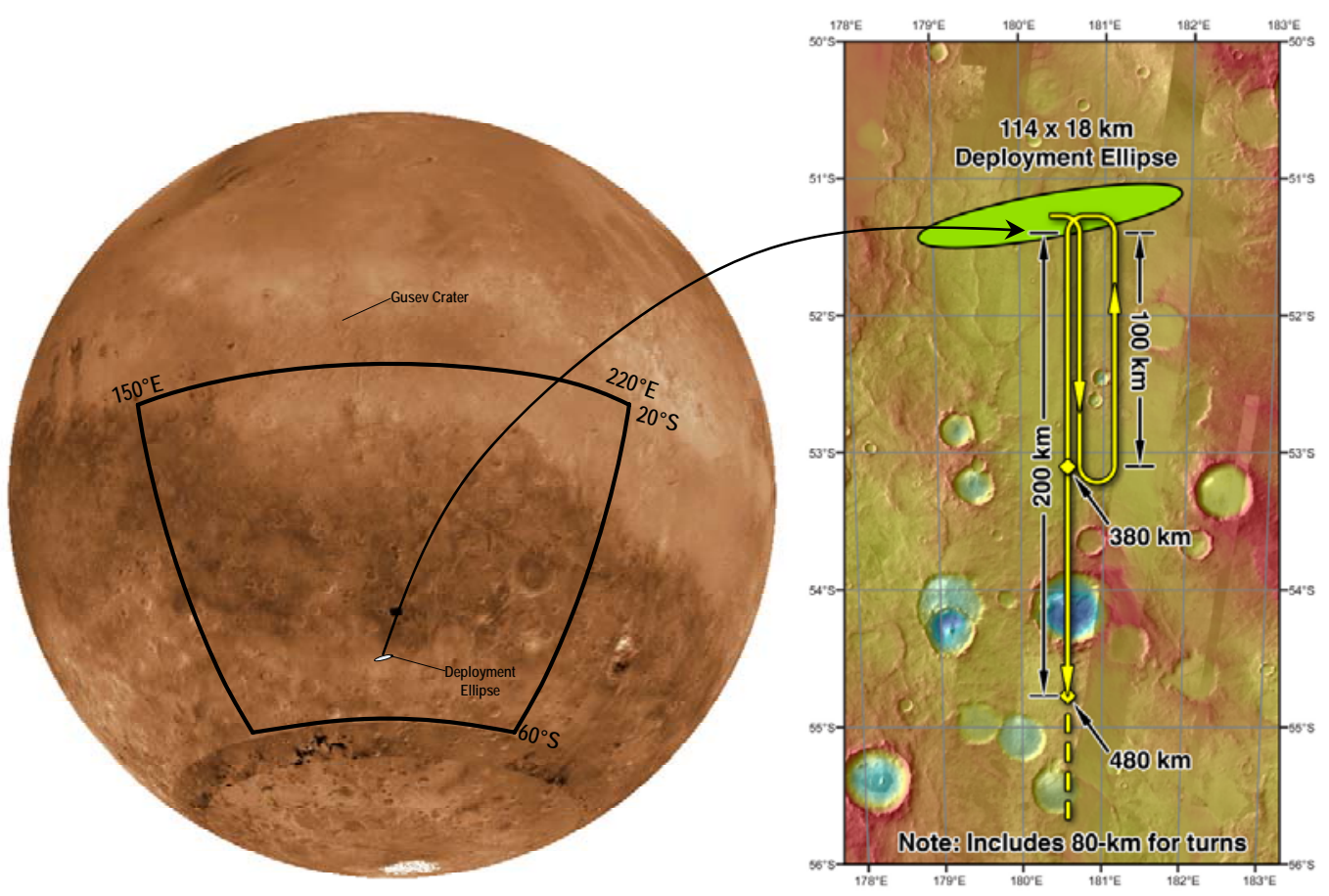

Figure 2. Target Region. $-20^{\circ}$ to $-60^{\circ}$ Latitude, $180^{\circ}$ Long $\left(+/-30^{\circ}\right)$

American Institute of Aeronautics and Astronautics 092407 
parallel North-South tracks, each of length $100 \mathrm{~km}$, shown in Figure 2. Data is relayed to the fly-by spacecraft and by a redundant path to the MRO orbiter. At the end of the traverse, the airplane impacts the surface, ending the atmospheric flight segment of the mission. No data is assumed to be transmitted from the airplane after surface impact.

\section{Atmospheric Flight System (Airplane)}

The ARES Atmospheric Flight System (AFS) includes the airplane, its subsystems and the science payload. Continued analyses and focused trade studies, augmented by experimental results from wind-tunnel and flight testing have matured the airplane and subsystem designs well beyond the fundamental conceptual level. A robust airplane configuration has been achieved through several design cycles, resulting in significant vehicle performance and reliability improvements. The airplane geometry is depicted in Figure 3. Delivery of the ARES airplane into the atmosphere of Mars requires an entry aeroshell. The primary configuration constraint is packaging of the airplane into the entry aero-shell in a way that accommodates the environments of launch and entry (Figure 4). The airplane shape is derived from the aero-shell packaging constraints and the need for subsonic flight required by the science measurements. Table 1 provides the overall mass and geometric properties for the Atmospheric Flight System ${ }^{1}$.
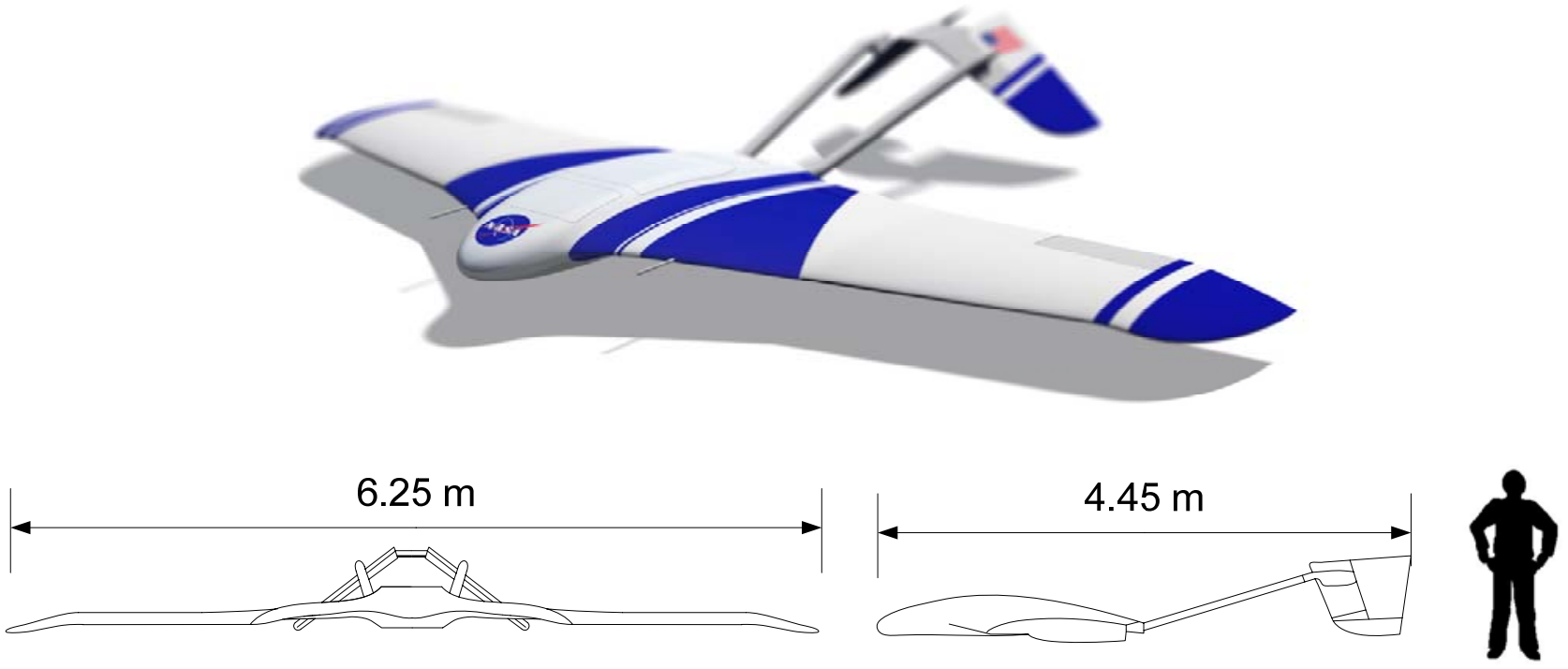

Figure 3. ARES Airplane Geometry

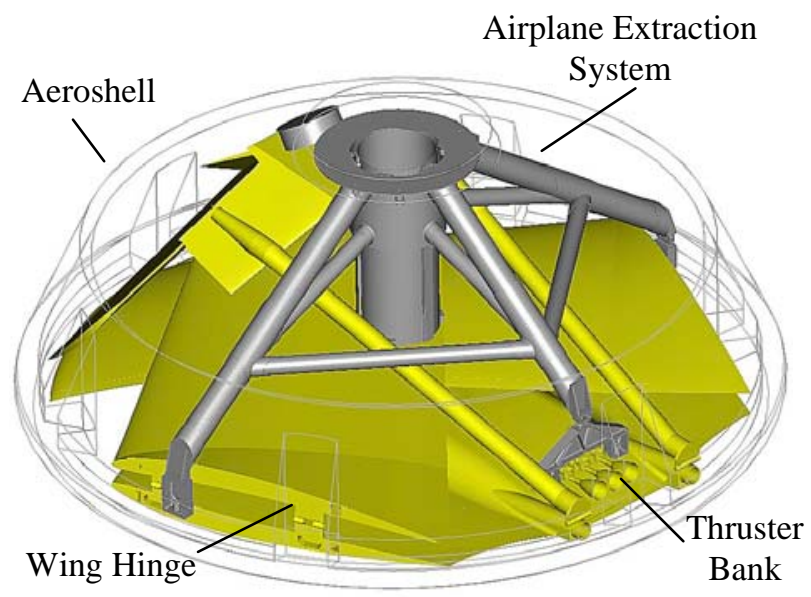

Table 1. ARES Airplane Parameters

\begin{tabular}{|l|l|}
\hline Parameter & Value \\
\hline Wing Span & $6.25 \mathrm{~m}$ \\
\hline Overall Length & $4.45 \mathrm{~m}$ \\
\hline Overall Height & $0.7 \mathrm{~m}$ \\
\hline Reference Wing Area & $7.0 \mathrm{~m}^{2}$ \\
\hline Mean Aerodynamic Chord & $1.25 \mathrm{~m}$ \\
\hline Dry Mass (CBE) & $112 \mathrm{~kg}$ \\
\hline Propellant Load & $45 \mathrm{~kg}$ \\
\hline Cruise Speed & $145 \mathrm{~m} / \mathrm{s}$ \\
\hline
\end{tabular}

Figure 4. ARES Airplane Aero-shell Configuration

American Institute of Aeronautics and Astronautics 


\section{Propulsion System Trade Studies}

The strict mass and volume limitations imposed by the aero-shell and Mars entry environment makes the propulsion system capabilities critical to establishing the airplane's performance and flight envelope. In selecting a propulsion system technology for the airplane, two competing criteria were used to evaluate each system; flight range and implementation risk. The first criterion for propulsion system selection is the ability of the airplane to achieve a science range requirement of at least $480 \mathrm{~km}$ of flight ${ }^{1}$. The second criterion relates to implementation risk of the propulsion system. The cost constraints and risk posture desired for Mars Scout missions require maximizing the use of existing, flight proven hardware. Extraction and deployment of the airplane from the aero-shell increases mission risk and any additional deployments necessitated by a propulsion system, such as propeller blades, are heavily considered in the final propulsion design. Various propulsion options, listed in Table 2, were examined to determine the candidate that best balanced the competing criteria of maximizing flight range and minimizing technical risk ${ }^{2}$. To stay within mass constraints of the $185 \mathrm{~kg}$ airplane, the propulsion subsystem total mass was constrained to a maximum of $63 \mathrm{~kg} ; 18 \mathrm{~kg}$ for hardware and about $45 \mathrm{~kg}$ for propellants. (During system design iterations, the amount of fuel varies slightly depending on available mass margin on the airplane). Results of the propulsion system analyses are listed in Table 2 and described below ${ }^{3}$.

Table 2. Comparison of Propulsion System Options

\begin{tabular}{|l|l|c|c|c|c|c|c|}
\hline Propulsion Category & \multicolumn{1}{|c|}{ System Description } & $\begin{array}{c}\text { Dry } \\
\text { Mass } \\
{[\mathbf{k g}]}\end{array}$ & $\begin{array}{c}\text { Fuel Load } \\
{[\mathbf{k g}]}\end{array}$ & $\begin{array}{c}\text { Flight } \\
\text { Hours }\end{array}$ & $\begin{array}{c}\text { Range } \\
{[\mathbf{k m ]}}\end{array}$ & TRL & $\begin{array}{c}\text { Development } \\
\text { Effort }\end{array}$ \\
\hline \multirow{2}{*}{$\begin{array}{l}\text { Electrical Propulsion } \\
\text { Systems }\end{array}$} & Fuel Cell & 48 & 15 & 3.0 & 1512 & $4-5$ & HIGH \\
\cline { 2 - 8 } & Battery & 63 & 0 & 0.4 & 202 & $4-6$ & MED \\
\hline \multirow{2}{*}{$\begin{array}{l}\text { Systems } \\
\text { Rocket Systems }\end{array}$} & Piston Expander Engine & 19 & 44 & 2.0 & 1008 & $4-5$ & HIGH \\
\cline { 2 - 8 } & 4 Cycle Combustion Engine & 21 & 42 & 4.1 & 2066 & $4-5$ & HIGH \\
\cline { 2 - 8 } & Bipropellant Rocket & 15 & 48 & 1.2 & 605 & $7-9$ & LOW \\
\cline { 2 - 8 }
\end{tabular}

\section{A. Electrical Propulsion Systems}

A simplified fuel cell system can be used to generate electrical power, which in turn can be used to power an electric motor and spin a propeller to generate thrust. This system can achieve flight of $1512 \mathrm{~km}$, carrying $15 \mathrm{~kg}$ of fuel with a $48 \mathrm{~kg}$ dry mass. The relative newness of the technology (TRL 4) and lack of experience in utilizing a fuel cell as the main power system in an airplane makes it a very high risk item.

A battery propulsion system is the simplest of all systems considered and requires fewer active controls and has no mechanical components, aside from the drive train. However, batteries with high specific power have low discharge rates. This low rate forces the battery capacity higher and adds significant mass to the system. The battery systems analyzed failed to satisfy the baseline science requirement, achieving a range of only $202 \mathrm{~km}$.

\section{B. Combustion Engine Systems}

The concept of using a piston expander engine as a primary propeller driver dates back to the first studies of Mars aircraft design in the late 1970's. The design is based on the Mini-Sniffer, high altitude, unmanned vehicle program ${ }^{4}$. The piston expander engine analysis shows a capability of $1008 \mathrm{~km}$ of flight carrying $44 \mathrm{~kg}$ of hydrazine and $19 \mathrm{~kg}$ of propulsion hardware. Piston expander technology remains at a TRL of $\sim 4-5$ and significant development would be needed to be implemented to produce an engine that can operate within the Mars environment.

The 4-cycle internal combustion engine option for Mars flight is similar to a conventional airplane engine but would require design changes to operate within the thin atmosphere of Mars using a bi-propellant. This option resulted in the longest flight range of $2066 \mathrm{~km}$, with a dry-mass of $21 \mathrm{~kg}$ and a hydrazine fuel load of $42 \mathrm{~kg}$. The combustion engine technology maintains a low TRL for a planetary flight application and would require a significant amount of design, testing and qualification for use in a Mars airplane.

\section{Rocket Systems}

Rocket propulsion systems have a long heritage in space flight applications and in specialized aircraft. There are a number of propellants that can power a rocket driven airplane within the Mars environment. Several propellant combinations were considered based on; specific impulse, a stable liquid state during interplanetary cruise, and spaceflight heritage ${ }^{2}$. Potential 
propellant combinations were narrowed down to one monopropellant and one bi-propellant option, listed in Table 3. Hydrazine has been used in spacecraft for several decades, typically in low thrust applications like satellite station keeping. Hydrazine is decomposed through a catalytic reaction with a metal oxide. The bi-propellant combination monomethyl hydrazine (MMH) and nitrogen tetroxide (MON3) is commonly used in the satellite industry for reaction control thrusters. Both hydrazine and MON3 have freezing points above expected interplanetary cruise environmental temperatures, and would therefore require active thermal control to stay liquid. The combination of MMH and MON3 has a much higher specific impulse than hydrazine but bi-propellant systems are typically more complicated than monopropellant systems.

Table 3. Rocket System Propellant Candidates

\begin{tabular}{|l|l|l|l|l|l|l|}
\hline Type & Propellant & Type & $\begin{array}{c}\text { Freezing } \\
\text { Point }\left({ }^{\circ} \mathbf{C}\right)\end{array}$ & $\begin{array}{c}\text { Density @ } \\
\mathbf{2 0} \mathbf{C}^{\circ} \mathbf{C} \\
\left(\mathbf{g m}^{3} \mathbf{\mathbf { c m } ^ { 3 }}\right)\end{array}$ & $\begin{array}{l}\text { Comb. } \\
\text { Temp. } \\
\left({ }^{\circ} \mathbf{C}\right)\end{array}$ & Isp (sec) \\
\hline $\begin{array}{l}\text { Mono- } \\
\text { propellant }\end{array}$ & Hydrazine $\left(\mathrm{N}_{2} \mathrm{H}_{4}\right)$ & Fuel & $1.5^{\circ} \mathrm{C}$ & 1.008 & 633 & $199-230$ \\
\hline $\begin{array}{l}\text { Bi- } \\
\text { Propellant }\end{array}$ & $\begin{array}{l}\text { Monomethyl Hydrazine }(\mathrm{MMH})\left(\mathrm{N}_{2} \mathrm{H}_{6} \mathrm{C}\right) \\
\text { Nitrogen Tetroxide (MON3) } \\
\left(97 \% \mathrm{~N}_{2} \mathrm{O}_{4}, 3 \% \text { NO by weight }\right)\end{array}$ & $\begin{array}{l}\text { Fuel } \\
\text { Oxidizer }\end{array}$ & $\begin{array}{l}-52.5^{\circ} \mathrm{C} \\
-11.2^{\circ} \mathrm{C}\end{array}$ & $\begin{array}{l}0.874 \\
1.39\end{array}$ & 3122 & $285-310$ \\
\hline
\end{tabular}

To evaluate the rocket propulsion system options, a number of designs were considered. These ranged from passive blow-down systems to regulated systems that were controlled either by on / off pulsing or by controlling the propellant flow to the thruster ${ }^{2}$. For each type of control scheme, both monopropellant and bipropellant systems were considered. The analysis of rocket systems resulted in a flight range of $605 \mathrm{~km}$ for the bi-propellant system and $454 \mathrm{~km}$ for the monopropellant system. Rocket propulsion systems, due to extensive use in military applications and the satellite industry, maintain a high technology readiness level between 7 and 9, which is the desirable technology maturation level for a Mars Scout mission.

Two rocket systems were viable options for a Mars airplane application, a MMH/MON3 bi-propellant system and a hydrazine mono-propellant system. Brief consideration was given to use of a MON25 oxidizer because of its lower freezing temperature, but introducing this technology with relatively low flight heritage was inconsistent with the risk posture of the Scout program. The final selection was driven by a system analysis that examined the difference in available fuel load to support the flight range of the two systems. Since the monopropellant system is less complex, a potentially lower dry-mass would permit additional fuel load. However packaging constraints of the airplane require dual propellant tanks for the monopropellant system, resulting in essentially the same hardware configuration as the bipropellant system. Dry-mass difference between the two systems is therefore negligible, and overall performance is based solely on the specific impulse of each system. The airplane with a monopropellant propulsion system is not able carry enough fuel to achieve the baseline science requirement of $480 \mathrm{~km}$.

\section{Airplane Propulsion System Selection}

The final selection of a propulsion subsystem for the ARES airplane depended on options requiring minimal developmental effort and low technical risk while meeting science range requirements. For the electrical systems and combustion engines, a propeller is required to generate thrust, and there are significant challenges to operating a propeller in the Mars atmosphere. The propeller would need to operate near the sonic limit at its tip, which would place the blade operation in a low Reynolds number, high subsonic Mach number environment. This is outside the regime of conventional propeller design. Additionally, the size of the propeller would require it to be folded to fit within the aero-shell then deployed with the airplane during entry. Due to the aerodynamics and required deployment, the propeller would represent considerable risk for airplane operation. The technical risk caused by the need for a propeller eliminated the electrical and combustion engine systems. Additionally the monopropellant rocket was unable to meet the baseline range requirement. Consequently, the bipropellant rocket system was selected as the only option that meets range and low technical risk requirements for the ARES mission. 


\section{Bipropellant Rocket System Design}

The airplane propulsion system design was derived from typical bipropellant systems used on spacecraft such as the Near Earth Asteroid Rendezvous and on the Mars Observer. System design has been iterated through several trade studies to arrive at the current baseline. The system is a reliable, single-string architecture with redundancy existing only within the series-redundant check valves and within the thruster arrangement, where thrust margin and the ability to fly on two of three thrusters exists.

\section{A. System Schematic and Hardware Layout}

The airplane baseline propulsion design is a regulated bi-propellant system with pulsed thruster control. Major components of this system consist of fuel and oxidizer tanks, a helium pressure tank, pyrotechnic valves, check valves, and thrusters. Due to cost and schedule constraints of the Scout missions, commercial hardware with significant spaceflight heritage is desirable to minimize developmental effort. ARES has chosen commercially available "off-the-self" components for the propulsion hardware that best meet the performance requirements and have the necessary flight heritage to minimize program risk (Table 4). A schematic of this propulsion system is shown in Figure 5. A description of the function of each component is provided in Table 5.

Table 4. Propulsion System Components.

\begin{tabular}{|l|l|}
\hline \multicolumn{1}{|c|}{ Component } & Heritage \\
\hline Helium Pressurant Tank & Aircraft/missile pressure vessel \\
\hline Propellant Tanks / PMDs & Modified design of typical propellant tanks \\
\hline Bipropellant Thrusters & Intelsat VI >1000 flown \\
\hline Thruster Valves & BSS-601, BSS-701, Star-2, Muses-C, Astro-E/F \\
\hline NC Pyrotechnic Valves & MRO, Various \\
\hline Liquid Filter & Various spacecraft/satellites \\
\hline GHe HP Filter & Various spacecraft/satellites \\
\hline Check Valves & Developed for Mars Ascent program \\
\hline Helium Regulator & Various Satellite programs \\
\hline Flow Venturis & Various \\
\hline HP Service Valves & Milstar derived \\
\hline Fluid Field Joints & Various \\
\hline Temperature Sensors & Analog Devices \\
\hline Pressure Transducers & EELV, Shuttle, TRW-ABL \\
\hline Thruster Valve Controller & TBD \\
\hline
\end{tabular}




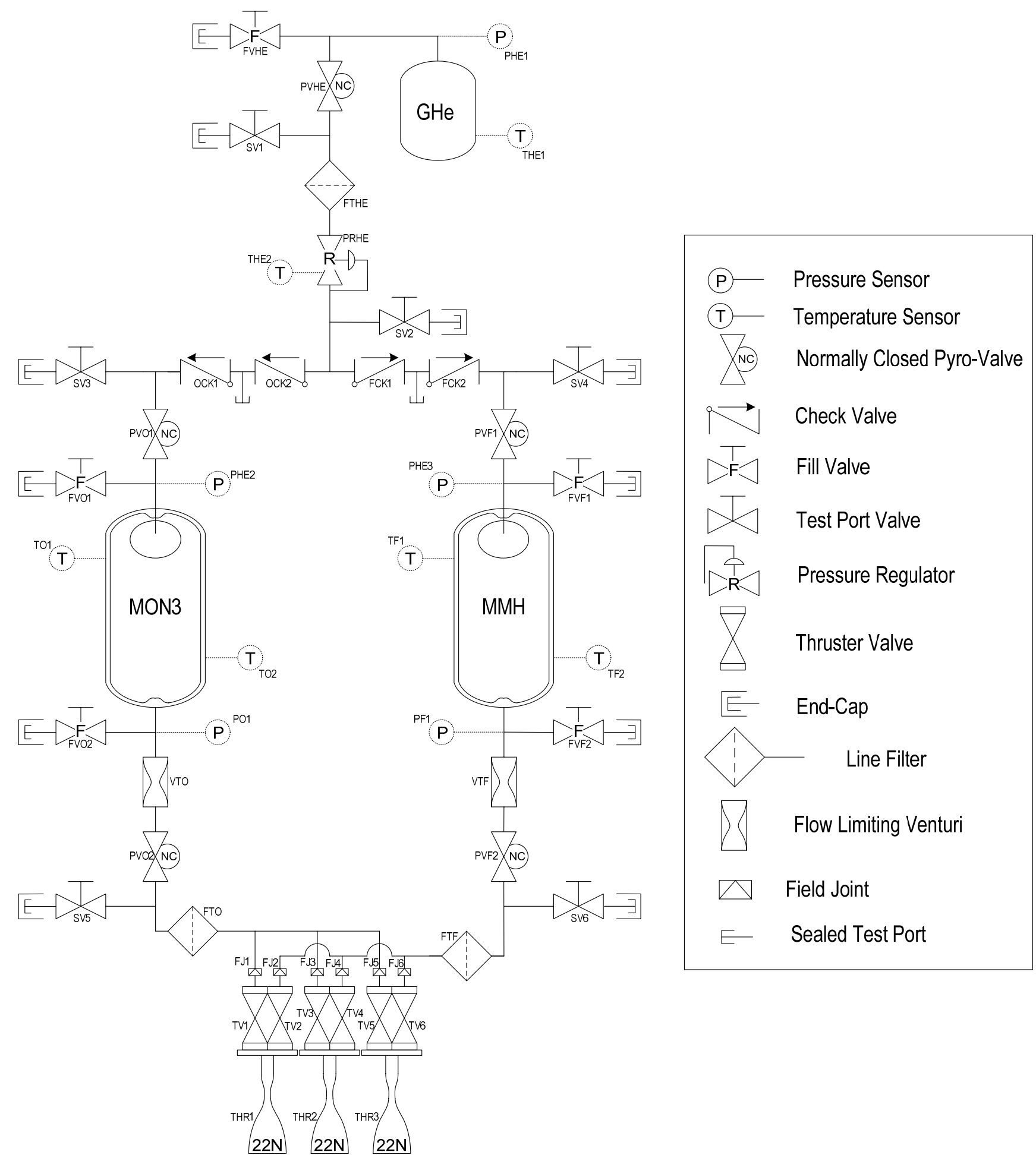

Figure 5. ARES Airplane Propulsion Subsystem Schematic 
Table 5. Propulsion Component Functional Descriptions

\begin{tabular}{|c|c|c|}
\hline GHe & Helium Supply & Provides high pressure helium (3000psi), used to pressurize propellant tanks to $300 \mathrm{psi}$ through regulator \\
\hline FVHE & Helium fill valve & Used for loading and off-loading helium. Capped before launch. \\
\hline PVHE & Helium Pyrovalve & $\begin{array}{l}\text { Used to isolate high pressure helium tank and protect helium pressure regulator PRHE from long term } \\
\text { exposure to high pressure during cruise. }\end{array}$ \\
\hline SV1 & Service Valve \#1. & Manual valve used for regulator functionality check at the system level. Capped before launch. \\
\hline FTHE & Helium line filter & $\begin{array}{l}\text { Located downstream of pyrovalve to filter debris from pyro activation event. Select line size finer than that } \\
\text { of thruster valve inlets. }\end{array}$ \\
\hline PRHE & $\begin{array}{l}\text { Helium pressure } \\
\text { regulator }\end{array}$ & $\begin{array}{l}\text { Regulates downstream pressure to propellant tanks to nominal } 300 \text { psig. Single regulator used since dual } \\
\text { would lead to increase propellant reserve required to cover mixture ratio uncertainty cause by possible } \\
\text { mismatched set points. }\end{array}$ \\
\hline SV2 & Service Valve \#2 & $\begin{array}{l}\text { Manual valve used for functionality and leak checking of the downstream series redundant check valves. } \\
\text { Capped before launch. }\end{array}$ \\
\hline FCK1 & $\begin{array}{l}\text { Fuel side check valve } \\
\# 1\end{array}$ & Series redundant check valves used to alleviate large mass flow of $\mathrm{MMH}$ into upstream helium section. \\
\hline FCK2 & $\begin{array}{l}\text { Fuel side check valve } \\
\# 2\end{array}$ & $\begin{array}{l}\text { Series redundant check valves used to alleviate I } \\
\text { A test port is located between the two check valves }\end{array}$ \\
\hline OCK1 & $\begin{array}{l}\text { Oxidizer side check } \\
\text { valve \#1 }\end{array}$ & Series redundant check valves used to alleviate large mass flow of MON3 into upstream helium section. \\
\hline OCK2 & $\begin{array}{l}\text { Oxidizer side check } \\
\text { valve \#2 }\end{array}$ & $\begin{array}{l}\text { 1ON3 into upstream helium section. } \\
\text { ality. }\end{array}$ \\
\hline SV3 & Service Valve \#3 & $\begin{array}{l}\text { Manual valve used for functionality and leak checking of the upstream series redundant check valves. } \\
\text { Capped before launch. }\end{array}$ \\
\hline SV4 & Servi & $\begin{array}{l}\text { Manual valve used for functionality and leak checking of the upstream series redundant check valves. } \\
\text { Capped before launch. }\end{array}$ \\
\hline PVO1 & $\begin{array}{l}\text { MON } \\
\text { Pyrov }\end{array}$ & $\begin{array}{l}\text { oid mixing of hypergolic fluids. MON3 vapors } \\
\text { ne. }\end{array}$ \\
\hline PVF1 & $\begin{array}{l}\text { MMH } \\
\text { Pyrova }\end{array}$ & d mixing of hypergolic fluids. MMH vapors \\
\hline FV01 & MON3 & of MON3 into tank. Capped before launch. \\
\hline FVO2 & MON & tank used fo \\
\hline FVF1 & MMH & nk. Cappe \\
\hline FVF2 & $\mathrm{MM}$ & Mant \\
\hline MON3 & MC & Tital \\
\hline $\mathrm{MMH}$ & M & Tita \\
\hline VTO & M & Use \\
\hline VTF & turi & Use \\
\hline PVO1 & $\begin{array}{l}\text { MON3 Downstream } \\
\text { Pyrovalve }\end{array}$ & avoid mixing of hypergolic fluids. \\
\hline PVF1 & $\begin{array}{l}\text { MMH Downstream } \\
\text { Pyrovalve }\end{array}$ & Used to positively isolate the upstream helium piping to avoid mixing of hypergolic fluids. \\
\hline SV5 & Service V & $\begin{array}{l}\text { Manual valve used for functionality testing of engine valves, system leak check, and to allow for positive } \\
\text { pad pressure to be established after testing. Capped before launch. }\end{array}$ \\
\hline SV6 & Service Valve \#6 & $\begin{array}{l}\text { Manual valve used for functionality testing of engine valves, system leak check, and to allow for positive } \\
\text { pad pressure to be established after testing. Capped before launch. }\end{array}$ \\
\hline FTO & MON3 Side Filter & $\begin{array}{l}\text { Located downstream of pyrovalve to filter debris from pyro activation event. Select line size finer than that } \\
\text { of thruster valve inlets }\end{array}$ \\
\hline FTF & MMH Side Filter & $\begin{array}{l}\text { Located downstream of pyrovalve to filter debris from pyro activation event. Select line size finer than that } \\
\text { of thruster valve inlets }\end{array}$ \\
\hline FJ1-6 & $\begin{array}{l}\text { Field Joints for } \\
\text { propellant lines }\end{array}$ & $\begin{array}{l}\text { Due to the OML of the airplane, thruster bank has to be installed separately from the rest of the propulsion } \\
\text { hardware. }\end{array}$ \\
\hline TV1-6 & Thrus & Thru \\
\hline THR1-3 & $22 \mathrm{~N}$ Thrusters & idently operated based on airplane control parameters. \\
\hline
\end{tabular}




\section{B. Propellant Tanks}

Two propellant tanks are needed to hold the fuel (MMH) and oxidizer (MON3). These tanks will be one of the few components in the propulsion system that will be specifically designed and developed for the ARES mission. Additionally, the internal propellant management devices (PMDs) will be new designs specifically tailored to the mission. The tanks shells and PMDs are not based on any existing flight hardware, however, the design and development is based on conventional spacecraft propulsion systems.

\section{Tank Shell Design}

The ARES fuel and oxidizer tanks are identical, cylindrical pressure vessels made of titanium, with a minimum wall thickness of $0.076 \mathrm{~cm}$ (0.03”), a maximum expected operating pressure (MEOP) of 300 psig. Tanks have external stiffener rings to endure vacuum loading. Internal volume constraints of the atmospheric flight system provide room for a tank diameter of $23.6 \mathrm{~cm}$ and a cylindrical barrel length of $32 \mathrm{~cm}$. Each tank shell has a mass of about $1.8 \mathrm{~kg}$. Composite over-wrapped propellant tanks were considered and could offer mass savings, but such a development would be inconsistent with the risk posture desired for a Scout proposal. A volume of approximately 24 liters per tank would allow a propellant load of $17 \mathrm{~kg}$ of MMH and $28 \mathrm{~kg}$ of MON3 to be accommodated with approximately $10 \%$ ullage and $0.5 \%$ residual volume.

\section{Propellant Management Device (PMD) Design}

Due to the unpredictable gravity and acceleration environment experienced by the airplane during flight, a Propellant Management Device (PMD) must be designed into the tanks to provide a continuous flow of oxidizer and fuel from the tanks to the thruster injection chambers. Continuous flow of liquid is required to maintain the

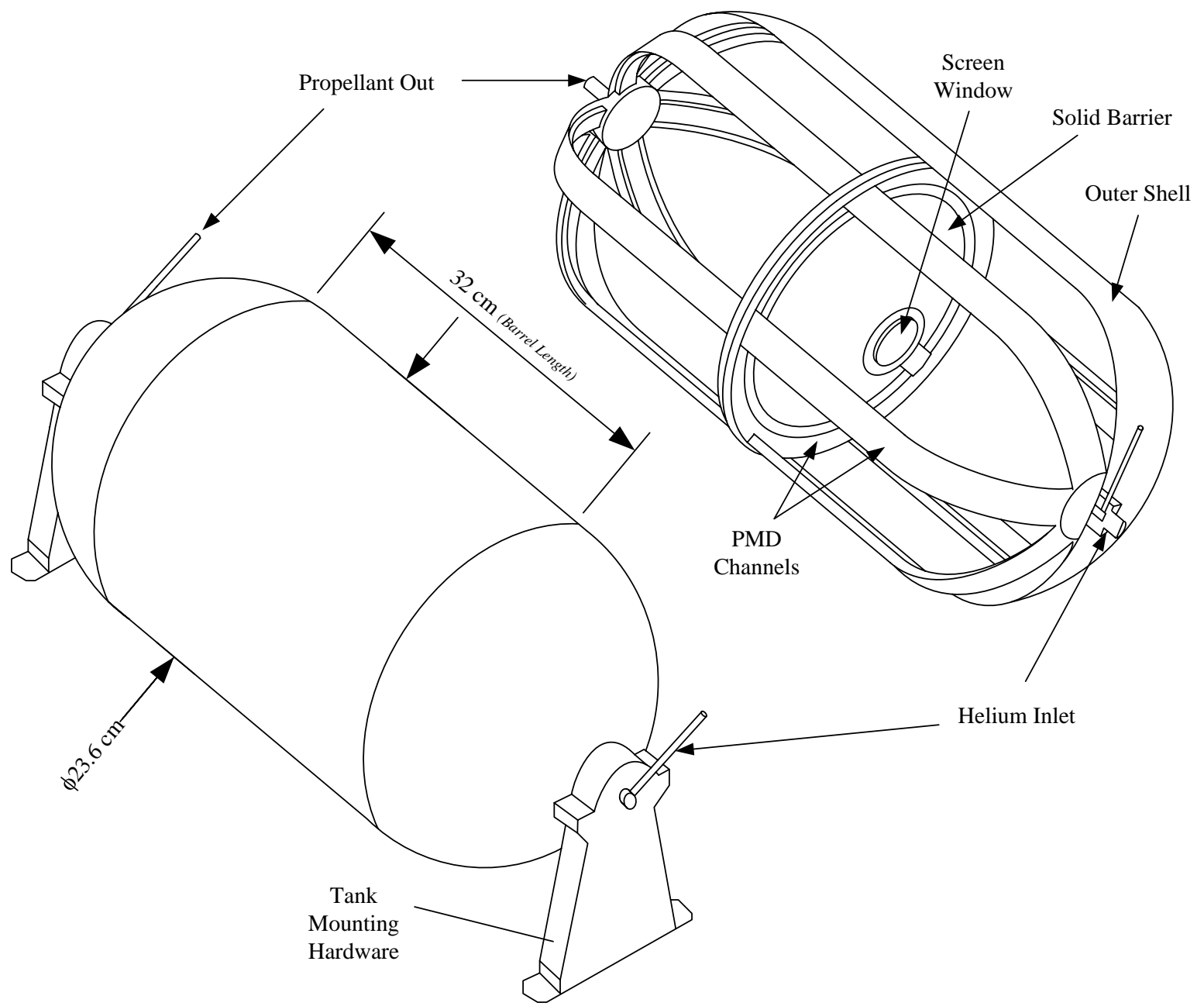

Figure 6. Propellant Tank and PMD Design

American Institute of Aeronautics and Astronautics 092407 
appropriate fuel/oxidizer mixture ratio in the injection chamber and to avoid pockets of helium gas in the liquid lines that could be inadvertently heated causing a burst in the system.

Several fuel extraction options were considered for the airplane, including metallic and elastomeric diaphragms, bellows, aerobatic airplane techniques, and traditional spacecraft concepts ${ }^{5}$. A conventional spacecraft screen and channel PMD was determined to be the most promising concept for the ARES airplane.

The screen-and-channel type propellant management devices (PMDs) inside each propellant tank are used to ensure that propellant can be acquired under Mars gravity or under any maneuvering or propulsive loads that may be encountered during airplane flight. A detailed design of the PMD concept resulted in a 6-channel totalcommunication PMD with 325x2300 stainless steel screens that will ensure gas-free propellant expulsion throughout the ${ }^{5}$. Stainless steel screens in the oxidizer tank will pose additional challenges that must be considered in the system design. Since the oxidizer (MON3) will leach iron from stainless steel leading to the formation of ferric nitrate, there is the potential for this compound to precipitate out of the oxidizer and obstruct flow passages. Titanium does not have this incompatibility with MON3, however, the bubble point for titanium screens is less than the maximum expected hydrostatic pressure which will permit gas to enter the PMD channels, which is undesirable. Therefore, stainless steel screens must be used along with a ferric nitrate risk mitigation strategy. The propellant tank design with internal PMD is shown in Figure 6.

A dynamic propellant slosh analyses was conducted based on the expected acceleration environment of the airplane during extraction and flight ${ }^{5}$. Along with the PMD channels, a center barrier acting as a baffle is included at the inside center of each tank to minimize sloshing during flight. A small screen window provides controlled movement of propellant between compartments. Residual propellant will exist in the tank when gas first enters the tank outlet. It is at this point when the propulsion system functionality is assumed to be over since gas in the liquidside propellant lines could burst the system tubing. The residual propellant in the tanks as well as propellant left in some of the PMD channels is estimated to be about 3-6\% of the original fuel load, resulting in an expulsion efficiency ranging from $94-97 \%$.

\section{E. Bipropellant Thruster Options}

The ARES airplane requires $40 \mathrm{~N}$ of thrust to maintain flight with a $50 \%$ margin to accommodate climbs, accelerations, and turbulent conditions. The first baseline airplane proposed in 2003 to the Mars Scout Program ${ }^{6}$ utilized a single $62 \mathrm{~N}$ thruster (AJ10-220) manufactured by Aerojet, which is the only heritage thruster available in this range of thrust. With concerns about the availability of tooling for manufacturing this thruster, as well as the non-recurring costs that would be imposed on the program (since the thruster is no longer in production), other options using more readily available thrusters were considered in a detailed trade study. This trade study was performed at NASA Langley Research Center under the Planetary Airplane Risk Reduction project in 2005 to examine the option of using multiple, smaller thrusters in place of a single large thruster with the goal to reduce overall cost, schedule, and technical risk ${ }^{7}$. The smaller thrusters that were considered included an array of various 5lbf $(22 \mathrm{~N})$ common reaction control thruster used on many satellites.

\section{F. AMPAC-ISP 22-N Columbium Thruster}

AMPAC-In-Space Propulsion (formerly Bell Aerospace and Atlantic Research Corporation) developed a family of $5 \mathrm{lbf}$ bipropellant engines using different valve configurations ranging from dual seat solenoid valves to single seat torque motor valves. These engines have demonstrated extremely long life of 100,000 seconds of steady state firing with high specific impulse ranging from $286-295 \mathrm{~s}^{8}$. These engines have also demonstrated wide flexibility of mission duty cycle operation by firing in any duty cycle ranging from 1-100\% and accumulating over 325,000 firing pulses on multiple units with a minimum of 400,000 pulses on one unit. The thrusters were designed, built, and qualified for the Intelsat VI series spacecraft. A diagram of the $22 \mathrm{~N}$ baseline thruster is shown in the airplane mounting configuration in Figure 7. Exit diameter is $5.4 \mathrm{~cm}$ and the total length of the thruster and attached valve, including shown inlet tubing, is approximately $27.3 \mathrm{~cm}$. The valve is shown with the Moog series redundant solenoid valve model Mg 51-178. A summary of performance characteristics of the $22 \mathrm{~N}$ thruster is shown in Table 6. 
Table 6. AMPAC-ISP 22N Thruster Characteristics ${ }^{8}$

\begin{tabular}{|l|l|}
\hline Fuel / Oxidizer & MMH / MON3 \\
\hline Thrust & $22 \mathrm{~N}$ \\
\hline Specific Impulse & $293 \mathrm{~s}$ \\
\hline Area Ratio & $150: 1$ \\
\hline Inlet Pressure Range & $94-400 \mathrm{psi}$ \\
\hline Feed Temperature & $70^{\circ} \mathrm{F} \mathrm{Nominal}$ \\
& $105^{\circ} \mathrm{F}$ Max SS Operation \\
& $160^{\circ} \mathrm{F}$ Pulsed Mode SS \\
\hline Chamber Press (nom) & 125 psia \\
\hline Max Impulse & $2,668,800 \mathrm{~N}-\mathrm{s}$ \\
\hline Min Impulse Bit & $0.045 \mathrm{~N}-\mathrm{s}$ \\
\hline Nozzle Exit Diameter & $5.4 \mathrm{~cm}$ \\
\hline End to End Unit Length & $27.3 \mathrm{~cm}$ (includes valve) \\
\hline Mass & $0.8 \mathrm{~kg}$ \\
\hline
\end{tabular}

\section{G. Thruster Mounting and Orientation}

Three thrusters are mounted on the airplane in an in-line configuration (Figure 7). Right hand and left hand thrusters are rotated about c.g. location by $4.5^{\circ}$ to allow for adequate clearance of the valves and propellant lines. Thrusters are tilted $5.88^{\circ}$ from the horizontal reference to direct thrust vector through the airplane c.g., shown in Figure 8.

The aft and forward brackets that hold the thrusters to the airframe are titanium alloy and are fabricated to place thrusters in correct orientation. The aft brackets are bolted to the valve flange using existing mounting holes. The thruster valve flange was chosen for bracket interface, because it only reaches a maximum temperature of $200^{\circ} \mathrm{F}$ at steady-state operation. The thrusters are also supported at the forward bracket and captured by titanium retaining rings. Once the retaining rings are placed into existing groove in valves, they are fastened to the forward bracket. The forward and aft brackets are bolted directly to composite airframe support structure. This design approach was to enable the ability to readily remove and reinstall the thrusters from the airframe during integration and testing.

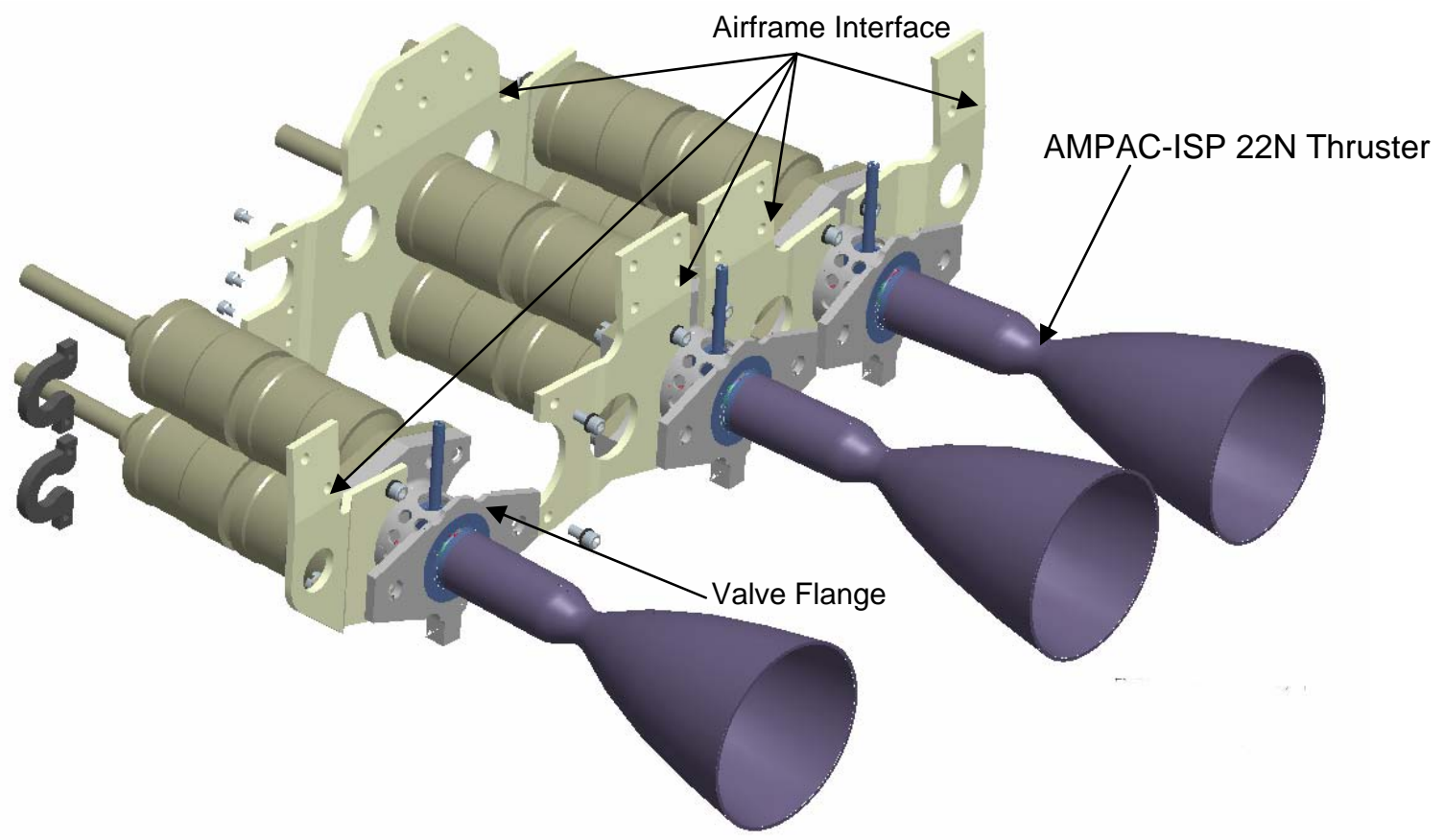

Figure 7. Triple 22N In-Line Thruster Mounting and Assembly 

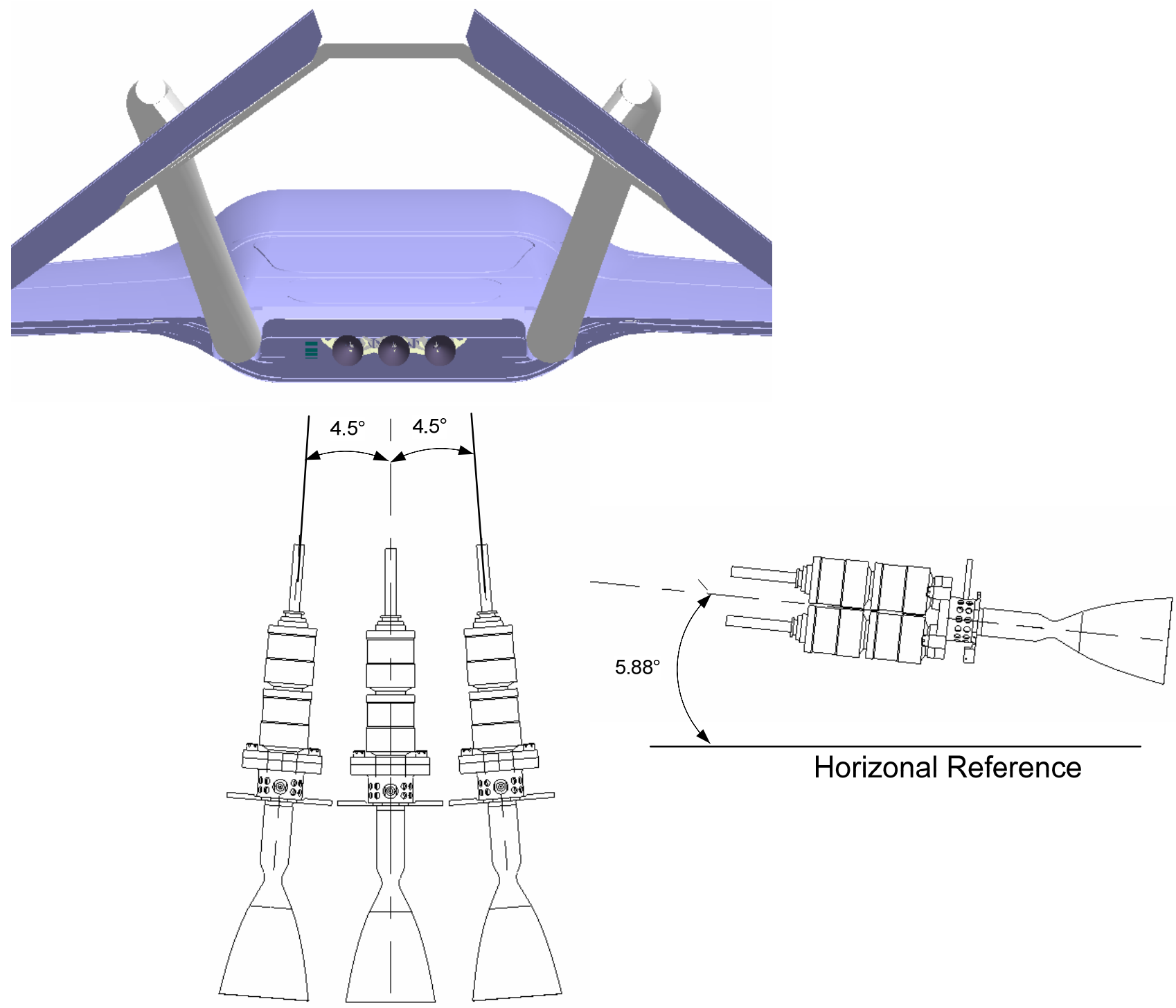

Figure 8. Thruster Orientation and Alignment

\section{H. Thruster Valves}

Thruster valve chosen for the ARES airplane propulsion system is the Moog 51-178 series redundant solenoid driven valve, shown mounted to the thruster in Figure 7. Each thruster has two independent valves to control the flow of fuel and oxidizer to the combustion chamber. These valves provide on/off flow capability by energizing solenoids from voltage signals provided by the propulsion valve driver card. The valve consists of stainless steel and Teflon ${ }^{\circledR}$ construction with a total mass of $0.19 \mathrm{~kg}$ and consumes 26 watts of power per valve when energized. The valve is normally closed with the Teflon ${ }^{\circledR}$ poppet and armature held against the valve seat by a suspension spring. When the valve coils are energized, the electromagnetic force overcomes the spring pre-load to lift the armature/poppet from the seat, providing a flow passage for the propellant. When the coil is de-energized, the spring forces the armature/poppet closed.

Since this valve is driven by electromagnetic forces, and the ARES science payload includes a magnetometry experiment, magnetic cleanliness of this valve is a key concern. A magnetic screening of this valve model was completed at NASA GSFC in June 2006 to measure the non-operating static field and the operating dynamic field. The test demonstrated a small static field ( $30 \mathrm{nT}$ at $1 \mathrm{~m} ; 0.2 \mathrm{nT}$ at $2.6 \mathrm{~m}$ ) and a small dynamic field $(60 \mathrm{nT}$ at $1 \mathrm{~m}$; $0.4 \mathrm{nT}$ at $2.6 \mathrm{~m}$ ) per coil when actuated. With a $2.6 \mathrm{~m}$ distance between the magnetometers and the thruster valves, and a $20 \mathrm{nT}$ static and $5 \mathrm{nT}$ dynamic magnetic cleanliness requirement, reductions of the thruster valve magnetic 
fields are desired but not required. Since these valves have series redundant solenoids, the valve can be successfully operated by reversing the current through one of the coils, which will result in cancellation of the magnetic field strength. This was successfully demonstrated in the screening resulting in a negligible reading of the dynamic field.

\section{Propellant Isolation and Flow Control}

Since the MMH and MON3 propellants are hypergolic, it is critical to ensure their isolation to avoid inadvertent ignition in any part of the feed system. Normally-closed, pyrotechnically-actuated valves ("pyro valves") (PVF1 and PVO1 in Figure 5) are used to isolate the high pressure helium supply from both propellant tanks and to prevent propellant vapor migration prior to system operation. Redundant series check valves are used to ensure that there is no fluid transfer or mixing of the hypergolic propellants during the operation of the system. The possibility exists, during the long periods of inactivity, for fuel or oxidizer to seep through the check valves and condense in upstream sections of the feed system. To minimize trapping any condensed propellant in dead-end upstream sections, the series-redundant check valves for the fuel and oxidizer are located upstream of the pyro valves, which provide the long duration isolation function. Downstream of the propellant tanks, normally closed pyro valves PVF2 and PVO2 are also used to provide a redundant seal against external leakage of the propellant through the single-seat thruster valves. In addition to increasing reliability, such redundant seals are required for safety during ground handling. All manual service valves also incorporate redundant seals.

\section{J. Hardware Integration}

Propulsion hardware must be packaged inside the limited volume of the airplane fuselage, along with all other hardware such as science instrumentation, avionics, communication components, power modules and support structure. Fuel and oxidizer tanks are each supported by two brackets with two mounting interfaces for each bracket that attach directly to the airplane structure. The helium tank is attached directly to the airframe through similar brackets. Propellant isolation and flow control hardware will be mounted to two separate honeycomb plates; the Propellant Isolation Assembly (PIA) Plate will consist of fuel and oxidizer pyrovalves, fill valves and service valves, and the Pressurant Control Assembly (PCA) Plate will consist of the helium tank pyrovalve, helium pressure transducer, check valves, and service valves. PIA and PCA plates will be mounted to the airframe structure using Torlon ${ }^{\circledR}$ thermal standoffs. Propellant and helium lines are supported by tube support assemblies which are bonded directly to the PIA and PCA plates and to the airframe structure. The propulsion hardware integrated within the airframe structure is shown in Figure 9.

The equipment list of all propulsion system components, number of flight units, mass and power, is shown in Table 7. The propellant tanks (with PMDs) are the most massive components at 5275 grams total, making up about $1 / 3$ of the total dry-mass of the system. The thruster valves use 26 watts each for a total of 156 watts of power required. Thruster valve power will not be continuous but rather cycled on and off when necessary to maintain flight. Additionally, not all thrusters will be firing simultaneously (see Section V). Total CBE dry mass of the propulsion system is $16.1 \mathrm{~kg}$ with a peak power requirement of 167 watts. 


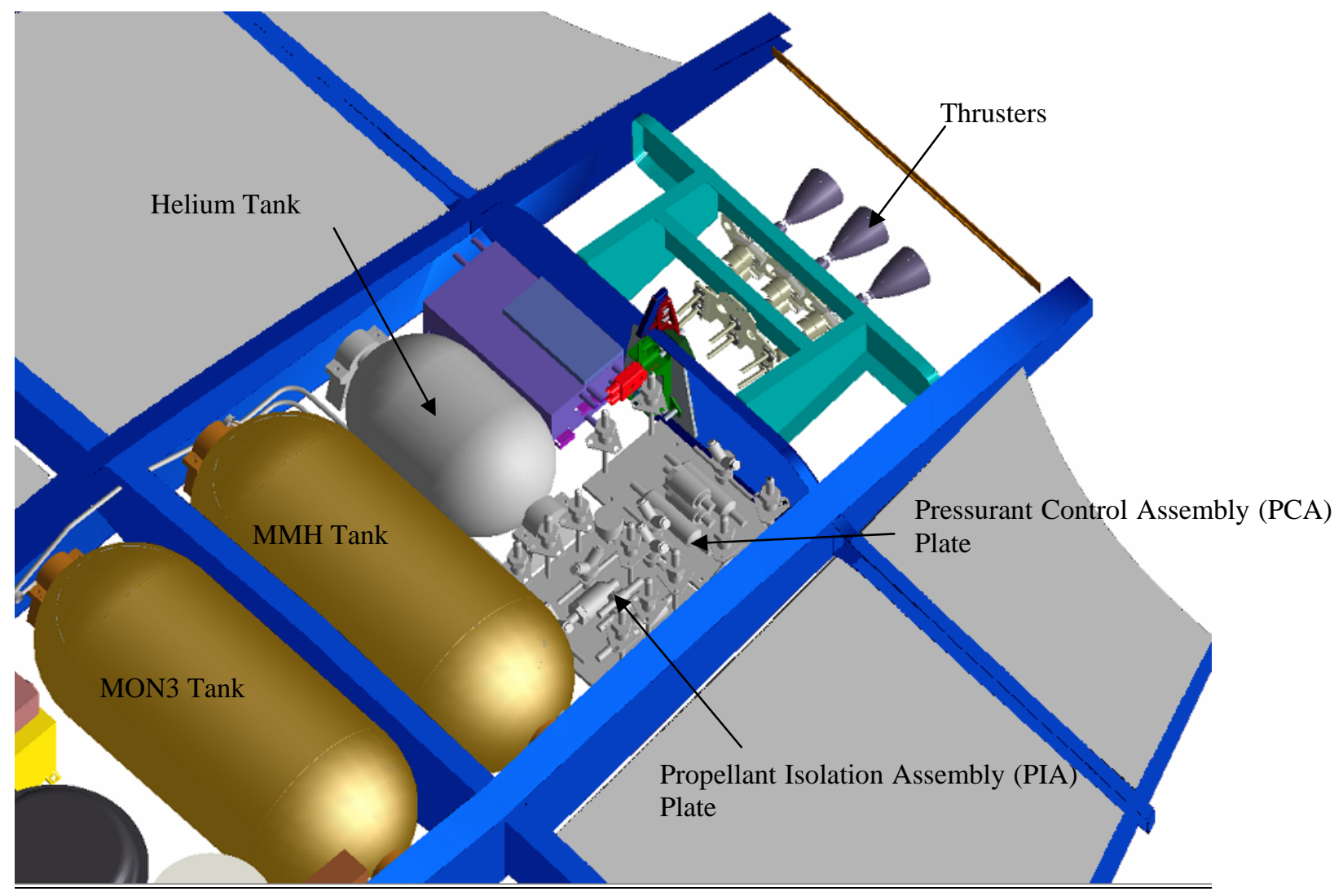

Figure 9. Propulsion System / Airframe Integration

Table 7. Propulsion System - Master Equipment List

\begin{tabular}{|l|c|c|c|}
\hline Component & \# Flight Units & Mass [grams] & Power [W] \\
\hline Bipropellant Thrusters & 3 & 1260 & - \\
\hline Thruster Valves & 6 & 1140 & 156.0 \\
\hline Propellant Tank Shell \& Stiffeners & 2 & 3228 & - \\
\hline Propellant Management Device (PMD) & 2 & 2046 & - \\
\hline Helium Pressurant Tank & 1 & 1200 & - \\
\hline Check Valves & 4 & 80 & - \\
\hline Helium Regulator & 1 & 550 & - \\
\hline Liquid Filter (MMH \& MON3) & 2 & 360 & - \\
\hline HP Service Valves & 11 & 1650 & - \\
\hline GHe HP Filter & 1 & 114 & - \\
\hline NC Pyro. Valves & 5 & 1020 & 5.0 \\
\hline High Pressure Transducer & 1 & 142 & 0.6 \\
\hline Low Pressure Transducer & 4 & 568 & 2.4 \\
\hline Flow Venturis & 2 & 80 & - \\
\hline Propellant Isolation Assembly (PIA) Plate & 1 & 100 & - \\
\hline Pressurant Control Assembly (PCA) Plate & 1 & 100 & - \\
\hline Thruster Valve Controller & 1 & 400 & 3.0 \\
\hline Thruster Valve Controller Chassis & 1 & 500 & - \\
\hline Lines, Tubing, Fittings & 1 & 739 & - \\
\hline Tank Support Brackets & 1 & 400 & - \\
\hline Residual Propellant \& Ullage & 1 & 434 & - \\
\hline Residual Helium Gas & 1 & 21 & - \\
\hline & & & \\
\hline TOTALS & 53 & 16132 & 167 \\
\hline
\end{tabular}

American Institute of Aeronautics and Astronautics 092407 


\section{System Performance}

ARES has analyzed the performance of the propulsion system through flight simulations and by characterizing its impact on other subsystems and airplane structures. The thermal environment created by the firing of the thrusters was examined as well as the potential impact of plumes on airplane structures and control surfaces.

\section{A. Thermal Impact of Thrusters}

During operation, the thrusters reach temperatures significantly greater than the expected $-60^{\circ} \mathrm{C}$ Mars ambient temperature. For continuous firing at room temperature, the combustion chambers of the thrusters reach approximately $1050^{\circ} \mathrm{C}$ in 45 seconds ${ }^{9}$. This creates a significant temperature difference between the thrusters and outer fuselage, which will cause a large radiative heat transfer between the two components. The airplane fuselage is a composite structure consisting of an aluminum honeycomb core surrounded by face sheets of carbon fabric. Adhesive holding the carbon face sheets to the aluminum honeycomb will begin to break down at approximately $250^{\circ} \mathrm{C}$. The valve flange, where the thruster bank will be mounted to the airframe, maintains a temperature near $100^{\circ} \mathrm{C}$ when the two outer thrusters are continuously firing. These two thruster will reach an equilibrium temperature profile similar to the one provided by the test firing, however it will be slightly cooler due to the much lower ambient temperature on Mars and forced convection from the thrusters to the atmosphere. The third thruster will be turned on and off as needed during flight.

Based on previous thermal analyses of the three thruster system, which included heat transfer from both the thruster nozzles and the plumes, the thruster support structure will experience a maximum temperature of $139^{\circ} \mathrm{C}$. However, an analysis of the lower fuselage without a heat shield (Figure ) shows temperatures reaching $284^{\circ} \mathrm{C}$, which exceeds the critical temperature $\left(125^{\circ} \mathrm{C}\right)$ of the face sheet to honeycomb film adhesive. Consequently, a thin polished aluminum heat shield will be required to reflect the heat away, which will result in significantly lower fuselage temperatures, shown in (Figure ). Further analyses and testing are required to obtain accurate plume temperature profiles for the expected airplane operating conditions.

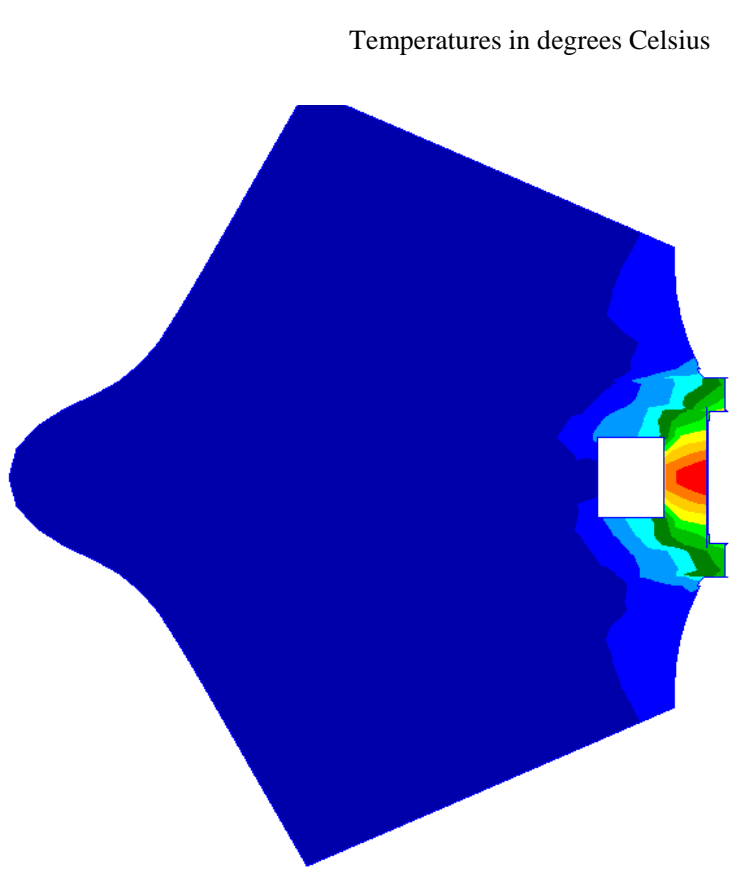

Figure 10. Temperature profile for lower fuselage without heat shield.

(Max Temperature $=284^{\circ} \mathrm{C}$ ).

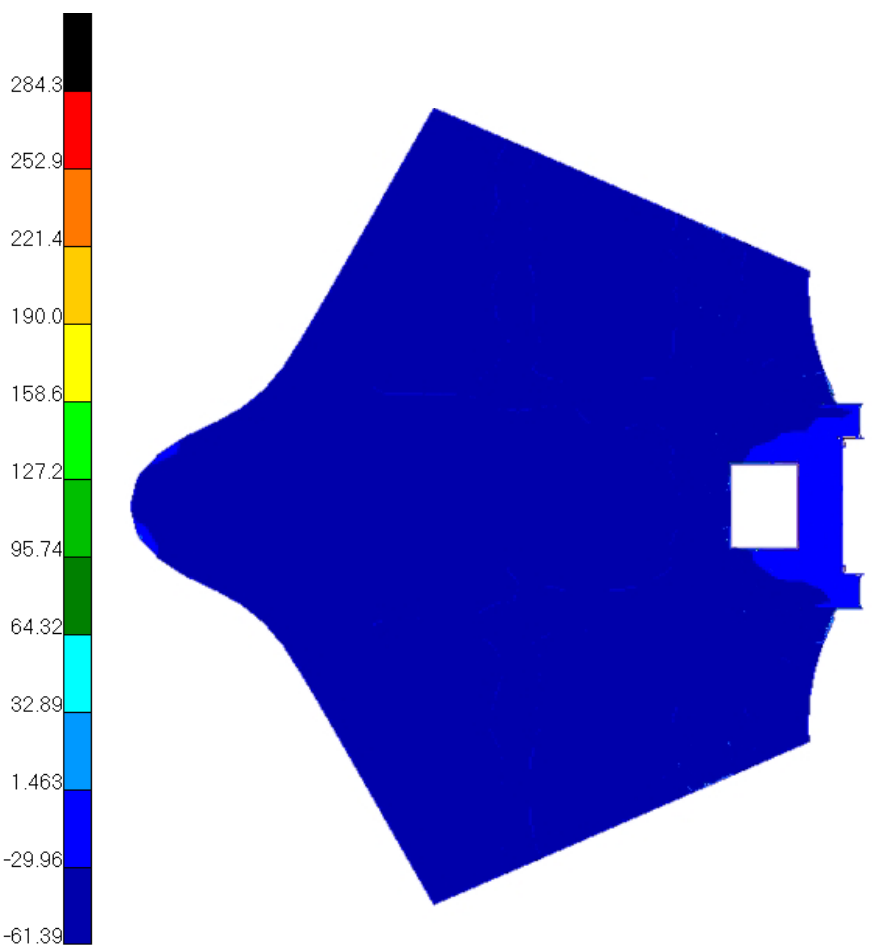

Figure 11. Temperature profile of lower fuselage with heat shield.

$\left(\right.$ Max $\left.T=-6.17^{\circ} \mathrm{C}\right)$. 


\section{B. Thruster Plumes}

Computational fluid dynamics simulations were used to evaluate possible plume interactions and aeropropulsive behavior of the airplane in the Mars atmosphere during coast and during thruster firing. A simulation modeled the 3D thruster system in a representative free-stream environment (using PAB3d and 6-DOF LaSRS). Figure shows a slice through the centerline plane of spanwise symmetry, with the center thruster plume visible in the lower picture. Here, the plume is seen to slowly bend from its initial $5.88^{\circ}$ incidence to align with the freestream flow. Figure shows a slice through the CFD simulation from the rear of the airplane. The individual thruster plumes (shown in the lower picture) are well isolated and maintain angular separation, with no major interactions apparent. Sufficient clearance exists between the tail and plumes to avoid any adverse affects of flight controls or performance.

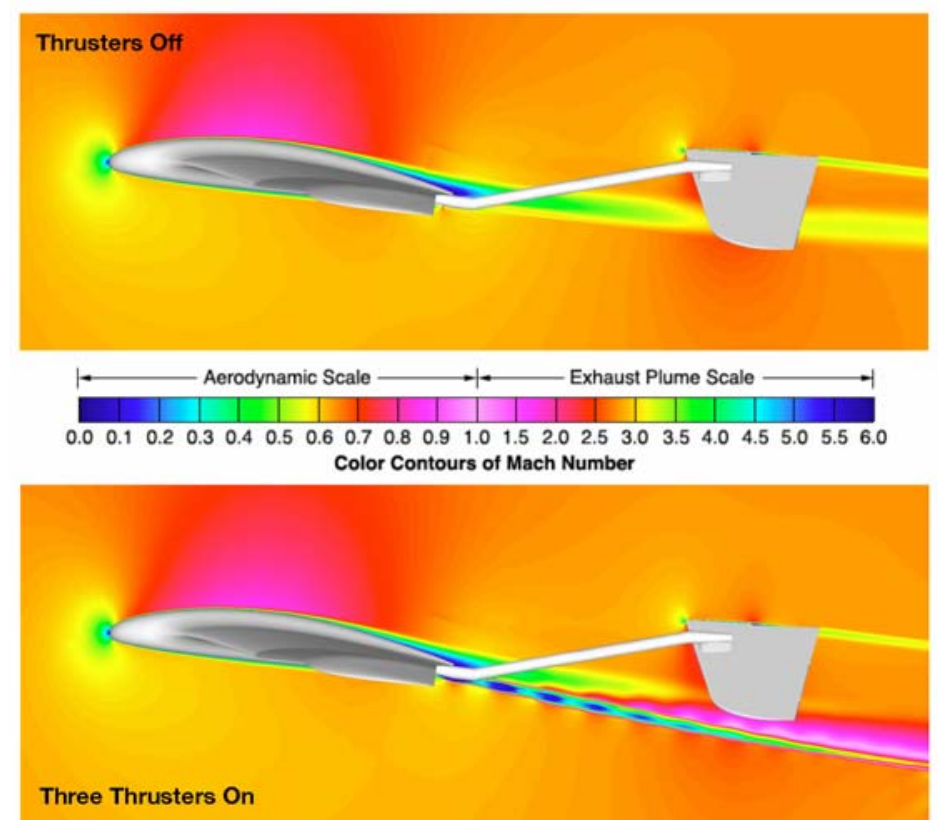

Figure 12. Side view of Airplane showing airplane in coast (above) and with thrusters firing (below).

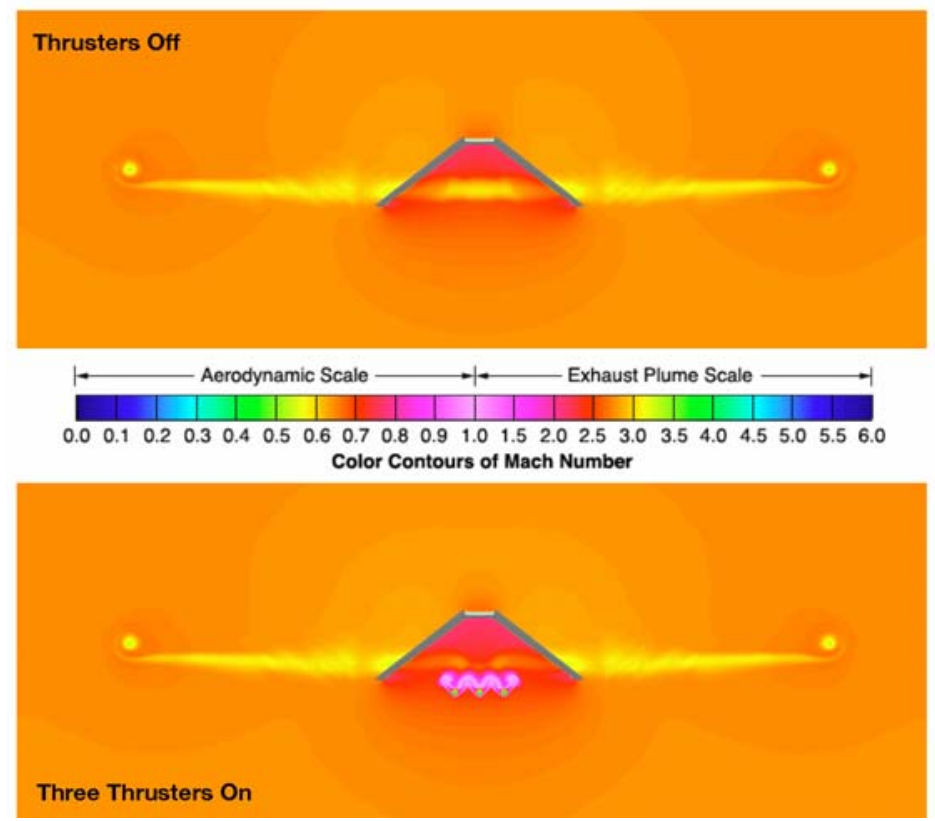

Figure 13. Rear view of Airplane showing airplane in coast (above) and with thrusters firing (below)

American Institute of Aeronautics and Astronautics 092407 


\section{Mars Atmospheric Flight Simulation}

The flight simulation of the Mars airplane was evaluated using a 6 degree-of-freedom model from the Langley Standard Real-Time Simulation application framework ${ }^{10}$. Control logic was incorporated to hold the airplane's speed while flying a specific mission profile. To control the thrust modulation in a pressure-blowdown propulsion system, on/off duty cycle adjustments are continuously generated by the control system. The firing logic for the thrusters is divided into two separate duty cycles. The primary duty cycle governs the firing of two outer thrusters simultaneously to provide the needed thrust to overcome drag while flying under normal conditions. The secondary duty cycle governs the firing of the third thruster and is invoked during instances where airplane acceleration or climbing is needed or under turbulent conditions when more than $44 \mathrm{~N}$ of nominal thrust is required to maintain flight.

Two atmospheric conditions were simulated to bound the upper and lower expected atmospheric conditions; one with no turbulence, and the other with severe atmospheric turbulence. For conditions of no turbulence, the two primary thrusters maintained a duty cycle of approximately $70 \%$, varying only between $60 \%$ and $85 \%$ for the majority of flight. The third thruster was only needed after pullout and initial stabilization of the airplane, and remained inactivate for the rest of the flight. During severe turbulence, the two primary thrusters are fully firing at $100 \%$ duty cycle (always on) for a significant portion of the flight, and that the third thruster, or secondary duty cycle, is sparsely invoked throughout the flight when needed and but still remains off for most of the flight.

The results of the simulation show that the airplane flying in no-turbulence conditions will achieve a range of about $612 \mathrm{~km}$ and duration of 70 minutes on a propellant load $45 \mathrm{~kg}$. In severe turbulence conditions for the same fuel load, the flight range is reduced only slightly, to a range approximately $608 \mathrm{~km}$ and a duration approximately 68 minutes.

\section{Conclusion}

The ARES Atmospheric Flight System involves a unique application of a liquid rocket propulsion system. This system enables the achievement of a set of unique Mars science objectives and fits within the ambitious constraints of Scout Mission. The technologies and engineering required for aerial flight on Mars will continue to be pursued, because of the potential for fundamental new understanding of the nature of atmosphere, surface, and interior that only an aerial platform can achieve, and which ARES is uniquely designed to accomplish, will compel an eventual aerial flight on Mars.

\section{Acknowledgments}

The author would like to acknowledge and thank the following individuals for their contributions to the maturation of the Mars airplane propulsion system concept; Anthony J. Colozza (Analex Corporation, NASA GRC), Carl S. Guernsey (NASA JPL), and Henry S. Wright (NASA LaRC) for initial concept development and baseline propulsion system design. Mike McGee, Greg McAllister, Tim Fischer, and Carey Parish (Lockheed Martin) for in-depth propulsion system trade studies, propellant tank designs, PMD design, and overall system maturation. P. Sean Kenney (NASA LaRC) for flight simulation and propulsion system performance, Steven S. Gayle and David A. Paddock (NASA LaRC) for mechanical design and thruster mounting concept, Joseph Gasbarre and Salvatore Scola (NASA LaRC) for thruster thermal analyses, and Craig A. Hunter (NASA LaRC) for thruster plume CFD and aero-propulsion simulation.

\section{Acronymns}

$\begin{array}{ll}\text { AFS } & \text { Atmospheric Flight System } \\ \text { AGL } & \text { Above Ground Level } \\ \text { ARES } & \text { Aerial Regional-scale Environmental Survey } \\ \text { CFD } & \text { Computational Fluid Dynamics } \\ \text { COPV } & \text { Composite Over-wrapped Pressure Vessel } \\ \text { EELV } & \text { Evolved Expendable Launch Vehicle } \\ \text { GHe } & \text { Gaseous Helium } \\ \text { GRC } & \text { Glenn Research Center } \\ \text { GSFC } & \text { Goddard Space Flight Center } \\ \text { JPL } & \text { Jet Propulsion Laboratory } \\ \text { LaRC } & \text { Langley Research Center }\end{array}$




$\begin{array}{ll}\text { LaSRS } & \text { Langley Standard Real-Time Simulation } \\ \text { MEOP } & \text { Maximum Expected Operating Pressure } \\ \text { MGS } & \text { Mars Global Surveyor } \\ \text { MMH } & \text { Monomethyl Hydrazine } \\ \text { MON3 } & \text { Nitrogen Tetroxide with 3\% Mixed Oxides of Nitrogen } \\ \text { MRO } & \text { Mars Reconnaissance Orbiter } \\ \text { NO } & \text { Mixed Oxide of Nitrogen } \\ \text { PAB3d } & \text { NASA Langley 3-dimensional CFD code } \\ \text { PCA } & \text { Propulsion Control Assembly } \\ \text { PIA } & \text { Propulsion Isolation Assembly } \\ \text { PMD } & \text { Propellant Management Device } \\ \text { TCM } & \text { Trajectory Correction Maneuver } \\ \text { TRL } & \text { Technology Readiness Level }\end{array}$

\section{References}

1 “ARES, an Aerial Regional-scale Environmental Survey of Mars,” proposed in response to the NASA Office of Space Science Announcement of Opportunity NNH06ZDA002O for Mars Scout 2006 Missions, July 21, 2006.

2 Colozza, A.J., “Comparison of Mars Aircraft Propulsion Systems,” NASA CR-2003-212350, May 2003.

3 Kuhl, C.A., Wright, H, Hunter, C., NASA Langley Research Center, Hampton, VA; Guernsey, C., Jet Propulsion Laboratory, Pasadena, CA; Colozza, A., NASA Glenn Research Center, Cleveland, OH, "Liquid Rocket Propulsion for Atmospheric Flight in the Proposed ARES Mars Scout Mission,” AIAA-2004-3696. 40th

AIAA/ASME/SAE/ASEE Joint Propulsion Conference and Exhibit, Fort Lauderdale, Florida, July 11-14, 2004.

4 Reed, R.D. (1978), “High-Flying Mini-Sniffer RPV: Mars Bound,” Astronautics and Aeronautics, Vol. 16, No. 6, pp 26-39.

5 “Mars Airplane Propulsion Study - Final Report,” NASA Contract NAS1-00141, Lockheed Martin Astronautics, April 19, 2005.

6 “ARES, an Aerial Regional-scale Environmental Survey of Mars - Concept Study Report,” proposed in response to the NASA Office of Space Science Announcement of Opportunity AO 02-OSS-02 for Mars Scout investigations, April 30, 2003.

7 Kuhl, C.A., Gayle, S.W., Hunter, C.A., Kenney, P.S., Scola, S., Paddock, D.A., Wright, H.S., Gasbarre, J.F, “Trade study of multiple thruster options for the Mars Airplane concept,” NASA TM-2007-5349. June 2007.

8 Chazen, M.L., Bell Aerospace Textron, “Long Life 5 LBF Bipropellant Engines,” AIAA-85-1378, AIAA/SAE/ASME/ASEE 21st Joint Propulsion Conference, Monterey, California, July 8-10, 1985.

9 G. P. Purohit, P. A. Donatelli, J. R. Ellison (Hughes Space and Communications Co., El Segundo, CA), and V. K. Dhir (California, Univ., Los Angeles), “Transient thermal model of a film-cooled bipropellant thruster ,” AIAA2000-1071, Aerospace Sciences Meeting and Exhibit, 38th, Reno, NV, Jan. 10-13, 2000.

10 Kenney, P.S., "Simulating the ARES Aircraft in the Mars Environment," AIAA-2003-6579, 2nd AIAA "Unmanned Unlimited” Systems, Technologies, and Operations - Aerospace Conference, San Diego, California, September 15-18, 2003. 